"The perceived influence on organizational productivity: a perspective of a public entity"
AUTHORS
Paul Green

ARTICLE INFO

Paul Green (2016). The perceived influence on organizational productivity: a perspective of a public entity. Problems and Perspectives in Management, 14(22), 339-347. doi:10.21511/ppm.14(2-2).2016.10

DOI http://dx.doi.org/10.21511/ppm.14(2-2).2016.10

RELEASED ON Monday, 13 June 2016

JOURNAL

"Problems and Perspectives in Management"

FOUNDER

LLC "Consulting Publishing Company "Business Perspectives"

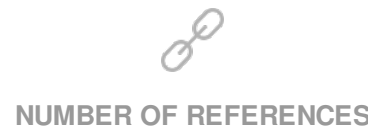

0
NUMBER OF FIGURES

0

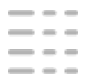

NUMBER OF TABLES

0

(C) The author(s) 2023. This publication is an open access article. 


\title{
The perceived influence on organizational productivity: a perspective of a public entity
}

\begin{abstract}
In an economic climate characterized by volatility, uncertainty, complexity and ambiguity, organizational productivity plays a more central role in determining success. There are many factors that impinge upon employees in their daily execution of duties that affect output. The purpose of this paper is to examine the factors that influence organizational productivity, specifically, from the viewpoint of its employees. The study draws upon a quantitative paradigm using a non-probability sampling technique. Data were collected from a total of 161 employees using a structured questionnaire across two different office sites in KwaZulu-Natal, South Africa. Statistical correlation tests were administered, and the findings indicate an association between organizational policies and employee benefit; organizational policies and performance appraisal; and performance appraisal and employee benefit. This research also confirms the findings of others, more significantly, in terms of reinforcing the perceptions of leadership and work-life balance as influential factors.
\end{abstract}

Keywords: organizational productivity, employee challenges, efficiency, leadership, South Africa.

JEL Classification: M2, L3.

\section{Introduction}

The prevalence of dissatisfaction among employees due to inhibiting factors within the organization is well documented in literature and leads to an abject effect on organizational productivity. The workplace environment plays a crucial role in the lives of employees. Amah and Ahiauzu (2013) suggest that organizations need to reconfigure their workplace in a manner that will allow employees to feel as an integral part of the organization. In South Africa, provincial government entities are experiencing numerous challenges in rendering efficient services. This sentiment is echoed by Gaffoor \& Cloete (2010) who claim that the demand for efficient and effective delivery of services in South Africa has increased in recent years. Over the past fifteen years, researchers have discovered that productivity is affected by relatively few influencers, and employees are, generally, cognizant of what those influencers are (Armstrong, 2006; Clawson \& Newburg, 2005; Hankin, 2004; Williams, 2003). Moreover, the issue of productivity of public organizations is very topical in South Africa. It is against this backdrop that the objective of this study was to examine the perceptions of government employees of a provincial department in South Africa on the challenges experienced and their effect on productivity. The paper presentation proceeds as follows: the problem statement with the aim and objectives of the study; a review of current literature on private sector versus productivity in a public sector and factors influencing productivity in the public sector; the conceptual framework of the study; and the methodology and analysis in which

(C) Paul Green, 2016.

Paul Green, Ph.D., Senior Lecturer, Department of Finance \& Information Management, Faculty of Accounting \& Informatics, Durban University of Technology, South Africa. descriptive statistics and correlations are presented. The final part of the paper provides a conclusion and recommendations, limitations of the study and directions for future research.

\section{Problem statement}

The topical issue of organizational performance within South Africa's public sector has received momentous research attention from a number of scholars (Minnaar, 2006; Molefe, Roodt \& Schurink, 2011; Mafini \& Pooe, 2013). Researchers (Carrim, 2009; Mulder \& Collins, 2007; Habib, 2010; Shaidi, 2013) are of the view that there is an expectation that government should supply public goods and services more effectively and efficiently. However, Nilsson (2010) holds the view that public sector organizations in South Africa find it difficult to overcome the challenge of underperformance of their operations.

Of equal importance to government is the well-being of their employees, and the effective and efficient implementation of national policy. Ellickson \& Logsdon (2001) mention environmental and personal characteristics as the two most influential variables that determine the level of employee satisfaction which has a positive influence on productivity. Research undertaken on performance issues and service delivery within the public sector in South Africa was done from a socio-economic perspective (Mafini \& Pooe, 2013), whereas this study attempts to examine the perceptions of employees from the public sector on the challenges experienced and their effect on productivity.

\section{Main aim}

The aim of this paper is to investigate perceptions of employees of a public entity on the factors impeding organizational productivity. 


\section{Research objectives}

The research objectives of this paper are as follows:

- to determine the perception of employees on the impact of these factors on organizational productivity; and

- to determine a correlation between the influential factors identified and demographics of a public entity in KwaZulu-Natal.

\section{Literature review}

Productivity is a ratio to measure how well an organization converts input resources (labor, materials, machines, money) into goods and services (Tokarčíková, 2013). Dorgan (1994) defines productivity as "the increased functional and organizational performance, including quality", and Rolloos (1997) claims that "productivity is that which people can produce with the least effort". Nda \& Fard (2013) describe employee productivity as the measure of output per unit of input economically. Rohan and Madhumita (2012) adopt a different view and see employee productivity as the $\log$ of net sales over total employees. Pritchard (1995) illustrates three definitions which relate to productivity:

1. is output/input, in other words, is a measure of efficiency;

2. is a composition of effectiveness and efficiency; and

3. whatever makes the organization function better.

It is worth noting and of particular interest in this study, whereby the context of the research is grounded in the public sector, and that researchers argue the differences in performance and productivity in the public sector versus the private sector (see Parker, Waller \& Hu, 2013).

4.1. Productivity in the public and private sector. Productivity in the public sector is viewed differently compared to productivity in the private sector as this is largely due to measurable outputs. The study conducted by Parker, Waller \& Xu (2013) begins by distinguishing three differences in productivity, i.e., manufacturing products; private commercial services; and public and notfor-profit services. The study reveals that the unit of measure and outputs of manufacturing operations are tangible and output can be measured while its quality characteristics can be objectively assessed. Conversely, in services, the output is intangible in nature (Green, 2006) making it difficult to quantify as the consumer also has emotional and psychological perceptions (Verma, 2012). Fee-paying customers are the determinants of value of private commercial services. Parker et al. (2013) state that the public and not-for-profit sector provide services that have no market price. These services are provided free of charge at point of use, e.g., library services. Contemporary literature shows that identifying the output of these types of services can be complex and problematic. This finding is supported by Sherwood (1994) who states that the key challenge in productivity measurement of all services relates to defining the basic unit of measuring the quantity of the services performed.

4.2. Factors influencing productivity in the public sector. Despite the various recent studies conducted on public worker motivation (Egberi, 2015; Abbass, 2012; Re'em, 2010) and productivity (Emerole, 2015; Haenisch, 2012; Ananti \& Umeifekwem, 2012), few, if any, have investigated the perception of public employees on organizational policies, employee benefit, performance appraisal, workplace relationships, leadership and work life balance as a combination of factors influencing productivity. It is noteworthy that these six factors are, by no means, exhaustive, but desktop research provides significant information that these factors are somewhat influential.

Tinofirei (2011) conducted a study on the unique factors affecting employee performance in nonprofit organizations. The study addressed external and internal factors affecting employee performance, and the results of the study illustrate three important findings. Employees were demotivated, firstly, due to the absence of automatic promotions for high performance, secondly, the lack of opportunities for the advancement of employees through a policy of competitive recruitment, and, thirdly, the absence of growth opportunities for local staff who can apply for international positions.

In another study, Emerole (2015) looked at the effect of non-monetary rewards on productivity of employees from a government parastatal in Nigeria. From a total of 78 civil servants selected across the parastatal, and using a multiple regression and a Pearson correlation coefficient, the study indicated the following:

- gender, age, monthly income, days of work in a month and type of non-monetary rewards received revealed negative significant contribution to the productivity of the sampled government parastatal; and

- educational qualifications, position/rank, and number of non-monetary rewards received revealed positive significant contribution to the productivity of the employees sampled. 
The study concludes that higher productivity and efficiency in governmental parastatals are possible with the effective exploitation of human resources through non-monetary rewards and recommends that government should motivate their staff by involving them in self-development programs with good remuneration payment and incentive packages.

\subsubsection{Conceptual framework.}

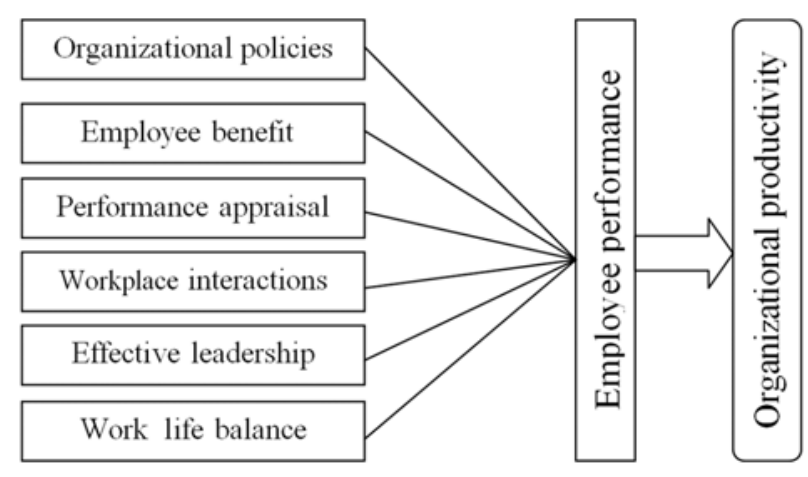

Fig. 1. Conceptual framework of the study

From the extant literature the author has selected six significant factors commonly cited as affecting employee performance which influences organizational productivity. The factors found in the framework are, by no means, the only factors influencing productivity in an organization, however, interviews with employees guided the selection of these factors.

4.2.2. Conceptual clarifications. Organizational policies: Mazerolle and Eason (2013) argue that some policies established by organizations are somewhat unsupportive of employees. Katou \& Budhwar (2010) are of the opinion that organizational policies impact on employees' job performance, particularly, Human Resource Management (HRM) policies.

Employee benefit: According to Ekere \& Amah (2014), employee benefit constitutes an integral part of the remuneration package. This benefit is seen to provide economic security for employees and, as a consequence, improve staff retention rates. A study conducted by Kwak and Lee (2009) reveal that some employee benefit is significantly associated with performance.

Performance appraisal: Performance appraisal has been used to improve performance and build both job satisfaction and organizational commitment (DeCarlo \& Leigh, 1996; Jaworksi \& Kholi, 1991). A study conducted by Cardy \& Dobbins (1994) found that, for performance appraisal to positively influence employee behavior and future development, employees must experience positive appraisal reactions.
Workplace interactions: Wu, Turban \& Cheung (2012) describe social exchange as 'an individual's voluntary actions towards another person that are motivated by an expected return from another person'. Social skills among employees allow them to effectively communicate with each other to enable a concerted effort towards accomplishing organizational goals. Schein (2006) asserts that a shared value is a set of social norms that define the rules or framework for social interaction and communication behaviors of society's members.

Effective leadership: Armstrong \& Murlis (2004) and Cronje, du Toit \& Motlatla (2001) affirm that leadership style within an organization has a strong bearing on encouraging or inhibiting an employee's performance.

Work-life balance: Nauert (2013) claims that employees are subjected to numerous challenges relating to balancing their lives and work commitments. Chittenden \& Ritchie (2011) state that most organizations are striving to formulate policies that are inclusive in nature. However, on the opposite end, Nauert (2013) argues that the support services offered by organizations are not sufficient as this may require a shift in organizational culture.

Employee productivity: Battu (2008), as cited in Anyim, Chidi \& Badejo (2012), states that employee productivity is the result of a combined employee ability, motivation and workplace environment. Okereke \& Daniel (2010) also suggest that employee productivity is a consequence of effectiveness and efficiency of the employees, while Chaudhary and Sharma (2012) posit that productivity is that which people can produce with the least amount of effort.

\section{Research design}

The study was empirically tested through a survey of employees selected from a public entity in the KwaZulu-Natal province of the Republic of South Africa. In adherence to ethical considerations, the name of the public entity has not been disclosed. The research study made use of a quantitative empirical design for collecting data from a large number of participants in a structured manner.

5.1. Sample. A non-probability convenience sampling method was used to obtain the sample for the research study. The employees of the public entity were targeted as the study sample population and, through random selection, a structured questionnaire was administered at the two different offices of the public entity. Employees from the Durban and Pietermaritzburg offices in KwaZuluNatal province of the Republic of South Africa were requested to participate in the research study. 
5.2. Research instrument and procedure. A twotier questionnaire was developed for the study. Section A of the questionnaire requested demographic information of the employees. Section $\mathrm{B}$ of the questionnaire was designed so that it contained a set of statements in which the respondent easily provides the level of agreement with the specified questions. The questionnaire comprised of two sub-scales measuring the impact of organizational policies, employee benefit, job performance, workplace relationship, effective leadership and work life balance on organizational productivity. The organizational policies exercise scale, employee benefit exercise scale and performance appraisal exercise scale comprised of 6 closed-ended items, 3 closed-ended items and 4 closed-ended items, respectively, which were all scored on a five-point Likert scale ranging from 1 (poor) to 5 (excellent). The workplace interactions exercise scale, leadership exercise scale, and work life balance exercise scale comprised of 4 closedended items, 10 closed-ended items and 6 closedended items, respectively, which were also scored on a five-point Likert scale ranging from 1 (strongly disagree) to 5 (strongly agree). A total of 161 questionnaires were distributed.

5.3. Data validity and reliability. A Cronbach's alpha coefficient of $0.776,0.818,0.783,0.889,0.906$ and 0.677 was obtained for organizational policies, employee benefit, performance appraisal, workplace interactions, leadership and work life balance, respectively, as shown in Table 1. This result shows that the data collected by this survey are reliable judging by most of the research variables obtaining a Cronbach's alpha $(\alpha)$ coefficient greater than 0.75 , except for work life balance.

Table 1. Reliability table for the research variables

\begin{tabular}{|l|c|c|}
\hline \multicolumn{1}{|c|}{ Research variable } & No of items & Cronbach's alpha $(\mathrm{a})$ \\
\hline Organizational policies & 6 & 0.776 \\
\hline Employee benefits & 3 & 0.818 \\
\hline Performance appraisal & 4 & 0.783 \\
\hline Workplace interactions & 4 & 0.889 \\
\hline Leadership & 10 & 0.906 \\
\hline Work life balance & 6 & 0.677 \\
\hline All research variables & 6 & 0.790 \\
\hline
\end{tabular}

5.4. Data analysis. The IBM Statistical Package for Social Sciences (SPSS - Version 22) was used to analyze the data collected from the distribution of the questionnaire. The data were analyzed in the following manner: descriptive statistics was used to report on the demographic characteristics of the sample; and mean ranking was used to summarize the organizational policies, employee benefit, performance appraisal, workplace interactions, leadership and work life balance associated with organizational productivity. A reliability test was used to determine the degree of reliability and internal consistency among the items.

\section{Results}

6.1. Descriptive statistics. This Section will present descriptive statistics on the demographics of the surveyed employees as well as their perceptions on the organizational policies, employee benefit, performance appraisal, workplace interactions, effective leadership and work life balance associated with productivity at the public entity.

6.1.1. Demographics. Descriptive statistics on the demographics of the employees (see Table 2) who participated in this study indicates that the majority of these employees are females. Of the 161 questionnaires administered, there were $62(38.5 \%)$ male participants and 99 (61.5\%) female participants. The age of the participants ranged from 20 -over 50 years, with the highest represented group $(52.2 \%)$ being in the $20-35$ years age group, followed by $36-50$ years $(40.4 \%)$ and over 50 years $(7.5 \%)$. Employees with less than 5 years' experience were the highest number of participants with a value of 71 (44.1\%), followed by employees with the experience level of over 10 years with a value of $57(35.4 \%)$ and employees whose experience level falls between 5 years and 10 years were least represented with a value of $33(20.5 \%)$.

Table 2. Demographics

\begin{tabular}{|c|c|c|c|}
\hline & \multicolumn{2}{|c|}{ Valid percent } & Missing \\
\hline \multirow{19}{*}{ Department } & Department 1 & 11.2 & \\
\hline & Department 2 & 17.4 & \\
\hline & Department 3 & 4.3 & \\
\hline & Department 4 & 6.2 & \\
\hline & Department 5 & 4.3 & \\
\hline & Department 6 & 6.2 & \\
\hline & Department 7 & 2.5 & \\
\hline & Department 8 & 3.7 & \\
\hline & Department 9 & 6.2 & \\
\hline & Department 10 & 6.8 & \\
\hline & Department 11 & 5.6 & \\
\hline & Department 12 & 6.8 & \\
\hline & Department 13 & 3.7 & \\
\hline & Department 14 & 3.1 & \\
\hline & Department 15 & 4.3 & \\
\hline & Department 16 & 3.1 & \\
\hline & Department 17 & 3.1 & \\
\hline & Department 18 & .6 & \\
\hline & Department 19 & .6 & \\
\hline \multirow{5}{*}{ Education Level } & Grade 12 & 18.0 & \multirow{5}{*}{.6} \\
\hline & Higher Certificate & 13.0 & \\
\hline & Diploma & 34.8 & \\
\hline & Bachelors/Honours & 31.1 & \\
\hline & Masters & 2.5 & \\
\hline
\end{tabular}


Table 2 (cont.). Demographics

\begin{tabular}{|c|c|c|c|}
\hline & \multicolumn{2}{|c|}{ Valid percent } & Missing \\
\hline \multirow{2}{*}{ Gender } & Male & 38.5 & \\
\hline & Female & 61.5 & \\
\hline \multirow{4}{*}{ Race } & Black & 66.5 & \\
\hline & Coloured & 7.5 & \\
\hline & Indian & 19.9 & \\
\hline & White & 5.6 & \\
\hline \multirow{3}{*}{ Age group } & $20-35$ years & 52.2 & \\
\hline & $36-50$ years & 40.4 & \\
\hline & Over 50 years & 7.5 & \\
\hline \multirow{3}{*}{ Employment duration } & $<5$ years & 44.1 & \\
\hline & $5-10$ years & 20.5 & \\
\hline & $>10$ years & 35.4 & \\
\hline
\end{tabular}

The perception of employees on the impact of these factors influencing organizational productivity.

6.1.2. Findings on organizational policies. Out of all the items used to determine the perception of employees on organizational policies, $11 \%$ of the respondents rate the development opportunities at the public entity as poor. $20 \%$ of the respondents rate the organization's communications policy as excellent. $74 \%$ of the respondents rate the organization's reporting structure as satisfactory.

6.1.3. Findings on employee benefit. Out of all the items used to determine the perception of employees on staff benefits, $22 \%$ of the respondents rate the organization's communication about staff benefits plans as poor. $66 \%$ of the respondents rate the value of their overall benefit plan as satisfactory. $23 \%$ of the respondents rate their satisfaction with the benefit service as unsatisfactory.

6.1.4. Findings on performance appraisal. Out of all the items used to determine the perception of employees on job performance and performance appraisal, $15 \%$ of the respondents rate employee recognition when an excellent job is done as poor. $64 \%$ of the respondents rate their understanding of the measures used to evaluate your job contribution as satisfactory. $26 \%$ of the respondents rate the performance feedback as unsatisfactory.
6.1.5. Findings on workplace interactions. Out of all the items used to determine the perception of employees on workplace interactions, $8 \%$ of the respondents strongly disagree with the way at which the supervisors resolve employee problems and labor issues. $11 \%$ of the participants strongly agree that managers show fairness and respect in their interactions with employees. $30 \%$ of the participants disagree that conflicts are resolved in a positive and constructive manner.

6.1.6. Findings on leadership. The results, obtained in the sub-scale Leadership, swayed largely towards disagreement. A high proportion of $72.10 \%$ indicated their level of disagreement with the statement The organization is effective in developing goals and integrating them into strategies for action. This was closely followed by The Leadership is willing to change to meet new objectives $(70.40 \%)$ and The Leadership is focused on a process of improvement $(66.30 \%) .40 \%$ of the participants disagree that leaders are open to feedback from multiple perspectives, while $64 \%$ of the participants feel that the leaders of the organization are not directing the organization in the right direction. Overall, the findings on the perception of Leadership are not seen to be very effective and adversely influence productivity.

6.1.7. Findings on work life balance. The staining within the sub-scale Work life balance contain two noteworthy statements. Firstly, a high percentage $(81.60 \%)$ are in disagreement with the statement $I$ understand the services offered by the organization's Employee Assistance Program. Secondly, 66.90\% are in disagreement with the statement I understand the policies related to overtime and alternate work arrangements. An alarming $60.80 \%$ of the respondents feel that the organization does not provide a way to receive confidential help when faced with personal problems that affect their work.

6.2. Correlations. The correlations between the research variables and the demographics of the sample are shown in Table 3, while Table 4 presents the corrections between the research variables.

Table 3. Correlation involving demographics

\begin{tabular}{|l|l|c|c|c|c|c|c|}
\hline \multicolumn{2}{|l|}{} & OP_T & BE_T & PA_T & WR_T & LE_T & WLB_T \\
\hline \multirow{4}{*}{ Department } & Pearson correlation & $.174^{*}$ & .035 & .139 & -.013 & -.056 & -.081 \\
\cline { 2 - 9 } & Sig. (2-tailed) & .028 & .662 & .081 & .875 & .491 & .313 \\
\cline { 2 - 9 } & $\mathrm{N}$ & 159 & 161 & 158 & 160 & 154 & 157 \\
\hline \multirow{4}{*}{ Education level } & Pearson correlation & .060 & -.023 & -.006 & .142 & .137 & -.110 \\
\cline { 2 - 9 } & Sig. (2-tailed) & .452 & .774 & .938 & .074 & .090 & .171 \\
\cline { 2 - 9 } & $\mathrm{N}$ & 158 & 160 & 157 & 159 & 153 & 156 \\
\hline \multirow{3}{*}{ Gender } & Pearson correlation & -.031 & -.003 & -.042 & .098 & .026 & .016 \\
\cline { 2 - 9 } & Sig. (2-tailed) & .700 & .968 & .597 & .218 & .749 & .841 \\
\cline { 2 - 9 } & $\mathrm{N}$ & 159 & 161 & 158 & 160 & 154 & 157 \\
\hline
\end{tabular}


Table 3 (cont.). Correlation involving demographics

\begin{tabular}{|c|c|c|c|c|c|c|c|}
\hline & & OP_T & $\mathrm{BE}_{-} \mathrm{T}$ & PA_T & WR_T & LE_T & WLB_T \\
\hline \multirow{3}{*}{ Race } & Pearson correlation & -.078 & .010 & -.043 & -.092 & -.097 & .003 \\
\hline & Sig. (2-tailed) & .331 & .899 & .597 & .248 & .231 & .966 \\
\hline & $\mathrm{N}$ & 158 & 160 & 157 & 159 & 153 & 156 \\
\hline \multirow{3}{*}{ Age group } & Pearson correlation & -.081 & .115 & -.035 & $-.227^{* *}$ & $-.232^{* *}$ & -.108 \\
\hline & Sig. (2-tailed) & .308 & .146 & .660 & .004 & .004 & .177 \\
\hline & $\mathrm{N}$ & 159 & 161 & 158 & 160 & 154 & 157 \\
\hline \multirow{3}{*}{ Employment duration } & Pearson correlation & $-.229^{* \prime}$ & -.055 & -.138 & $-.229^{* *}$ & $-.229^{* *}$ & -.085 \\
\hline & Sig. (2-tailed) & .004 & .489 & .084 & .004 & .004 & .288 \\
\hline & $\mathrm{N}$ & 159 & 161 & 158 & 160 & 154 & 157 \\
\hline \multicolumn{8}{|c|}{${ }^{*}$. Correlation is significant at the 0.05 level (2-tailed) } \\
\hline \multicolumn{8}{|c|}{${ }^{* \star}$. Correlation is significant at the 0.01 level (2-tailed) } \\
\hline
\end{tabular}

The following relationship can be observed in Table 3:

R1 - (Department): A negative correlation was observed between Department and workplace interactions (-0.013), Department and Leadership $(-0.056)$ and Department and Work life balance $(-0.081)$. These findings might be suggesting that workplace interactions, inefficiency of leaders and work life balance will have a negative impact on productivity of organization's departments if they are not considered when accessing the departments. A weak positive correlation was observed between department and organizational policies suggesting that organizational policies barely contribute to the development of a department.

R2 - (Education level): A negative correlation was observed between Education level and employee benefit (-0.023), Education level and Performance appraisal (-0.006) and Education level and Work life balance (-0.110). These findings might be suggesting that a high level of education does not guarantee high employment benefit or high job performance or ability to create a balance between work and life activities. A weak positive correlation was observed for organizational policies (0.060), workplace interactions (0.142) and leadership (0.137).

R3 - (Gender): A negative correlation was observed between Gender and organizational policies (-0.031), Gender and employee benefit $(-0.003)$ and Gender and performance appraisal $(-0.042)$. This might be suggesting that Gender consideration is highly important in the organization, especially in the area of policy development, employee benefit restructuring and employee's performance evaluation. A weak positive correlation was observed for workplace interactions (0.098), leadership (0.026) and worklife balance (0.016).
R4 - (Race): A negative correlation was observed between Race and organizational policies $(-0.078)$, Race and performance appraisal (-0.043), Race and workplace interactions (-0.092), and Race and leadership (-0.097). These findings might suggest that disbanding of racial discrimination goes a long way in building workplace relationships, improving leader's interactions with the employees, increasing the performance of the employees, and creating good organizational policies. A weak positive correlation was observed for employee benefit $(0.010)$ and work life balance (0.003).

R5 - (Age group): A negative correlation was observed between Age group and organizational policies (-0.081), Age group and performance appraisal (-0.035), Age group and workplace interactions (-0.227), Age group and leadership $(-0.232)$, and Age group and work life balance $(-0.108)$. These findings might be suggesting that age group plays an important role in the organization's productivity, especially in the area of workplace interactions (i.e., employees of the same age group tend to relate together), performance appraisal, leadership (i.e., consideration of a younger age group for a leadership position might be a wrong step due to lack of experience). A weak positive correlation was observed for employee benefit (0.115).

R6 - (Employment duration): A negative correlation was observed between Employment duration and organizational policies (-0.229), Employment duration and employee benefit (-0.055), Employment duration and performance appraisal (-0.138), Employment duration and workplace relationship (-0.229), Employment duration and leadership (-0.229), and Employment duration and work life balance (-0.085). These findings might be suggesting that the employment duration is highly essential in assessing the contribution of employees to the organization's productivity. 
Table 4. Correlation not involving demographics

\begin{tabular}{|c|c|c|c|c|c|c|c|}
\hline & & OP_T & BE_T & PA_T & WI_T & LE_T & $\overline{W L B}{ }_{-1}$ \\
\hline \multirow{3}{*}{$\mathrm{OP}_{-} \mathrm{T}$} & Pearson correlation & 1 & $.514^{\prime \prime}$ & $.552^{*+}$ & $.313^{* *}$ & $.469^{* *}$ & $.203^{*}$ \\
\hline & Sig. (2-tailed) & & .000 & .000 & .000 & .000 & .011 \\
\hline & $\mathrm{N}$ & 159 & 159 & 156 & 158 & 152 & 155 \\
\hline \multirow{3}{*}{$\mathrm{BE} \_\mathrm{T}$} & Pearson correlation & $.514^{* \prime}$ & 1 & $.509^{*+1}$ & $.261^{* *}$ & $.358^{* *}$ & $247^{*+}$ \\
\hline & Sig. (2-tailed) & .000 & & .000 & .001 & .000 & .002 \\
\hline & $\mathrm{N}$ & 159 & 161 & 158 & 160 & 154 & 157 \\
\hline \multirow{3}{*}{ PA_T } & Pearson correlation & $.552^{*+}$ & $.509^{* \prime}$ & 1 & $.475^{* *}$ & $.495^{* *}$ & $.288^{* *}$ \\
\hline & Sig. (2-tailed) & .000 & .000 & & .000 & .000 & .000 \\
\hline & $\mathrm{N}$ & 156 & 158 & 158 & 157 & 152 & 155 \\
\hline \multirow{3}{*}{ WI_T } & Pearson correlation & $.313^{*+}$ & $.261^{* \prime}$ & $.475^{* \prime}$ & 1 & $.634^{* *}$ & $.385^{* \prime}$ \\
\hline & Sig. (2-tailed) & .000 & .001 & .000 & & .000 & .000 \\
\hline & $\mathrm{N}$ & 158 & 160 & 157 & 160 & 154 & 156 \\
\hline \multirow{3}{*}{ LE_T } & Pearson correlation & $.469^{* \prime}$ & $.358^{* \prime}$ & $.495^{* \prime}$ & $.634^{* *}$ & 1 & $.455^{+*}$ \\
\hline & Sig. (2-tailed) & .000 & .000 & .000 & .000 & & .000 \\
\hline & $\mathrm{N}$ & 152 & 154 & 152 & 154 & 154 & 152 \\
\hline \multirow{3}{*}{ WLB_T } & Pearson correlation & $.203^{*}$ & $.247^{* *}$ & $.288^{* *}$ & $.385^{*}$ & $.455^{* *}$ & 1 \\
\hline & Sig. (2-tailed) & .011 & .002 & .000 & .000 & .000 & \\
\hline & $\mathrm{N}$ & 155 & 157 & 155 & 156 & 152 & 157 \\
\hline
\end{tabular}

Table 4 depicts the correlations observed between organizational policies and employee benefit (0.514), organizational policies and performance appraisal (0.552), performance appraisal and benefit (0.509), workplace interactions and leadership (0.634). These findings suggest that there is an associate relationship between the above sets of two factors albeit at mid-range scores.

\section{Conclusion and recommendations}

The main aim of this study was to investigate perceptions of employees of a public entity on the factors impeding organizational productivity. The study concludes that productivity in the public sector is viewed differently as opposed to the private sector as this is largely attributable to the varying measurable outputs, whereby the public sector is regarded as rendering an intangible output, and the private sector is seen to produce tangible outputs which are objective in nature and are measurable. In addition, from the desktop research conducted, the study outlines six factors influencing productivity within the public sector, viz., organizational policies, employee benefits, performance appraisal, workplace interactions, effective leadership and work life balance. Furthermore, the study concludes an association between organizational policies and employee benefits; organizational policies and performance appraisal; and performance appraisal and employee benefits. Congruence of this study's results with previous research in public entities indicates the potential for general applicability of the findings across the sector. Key factors appear to be leadership and work life balance as influential.
The recommendations are as follows:

- effective communication of Employee Assistance Programs should be offered by public entities;

- periodic training for line managers should be provided to improve managerial skills and to ensure that conflicts are resolved in a constructive manner; and

- management should implement structured career development opportunities, e.g., succession planning initiatives as well as staff retention policies.

\section{Limitations and future research}

This research has left several issues to be addressed. Firstly, the six factors selected as influential are, by no means, exhaustive, and there are opportunities to identify and research other influential factors. Secondly, there is a need to accurately determine a productivity index in a service organization, whereby output is measured against service quality. Finally, factors influencing productivity are the perceptions which relied upon subjective judgement of the employees and are, by no means, scientifically accurate, hence, a quantitative study using statistical tests will produce a more conclusive finding. However, the results obtained will be valuable to researchers and managers within the public sector.

Future research can be conducted using a longitudinal study to gain an understanding of the factors influencing employee productivity. Secondly, further studies should be conducted to determine a productivity index and perform a regression analysis between the influential factors and the productivity index. 


\section{References}

1. Abbass, I.M. (2012). Motivation and Local Government Employees in Nigeria, European Scientific Journal, 8 (18), pp. 129-141. Available at: http://eujournal.org. Accessed on 07 September 2015.

2. Amah, E. \& Ahiauzu, A. (2013). Employee involvement and organizational effectiveness, Journal of Management Development, 32 (7), pp. 661-674.

3. Ananti, M.O. \& Umeifekwem, U. (2012). Work Ethics and Productivity in Local Government Systems in Nigeria, Problems and Prospects, African Research Review, 6 (1), pp. 380-392.

4. Anyim, C.F., Chidi, O.C. \& Badejo, A.E. (2012). Motivation and Employees' Performance in the Public and Private Sectors in Nigeria, International Journal of Business Administration, 3 (1), pp. 31-40.

5. Armstrong, M. (2006). Handbook of human resource management practice (10th ed.). London, England: Kogan Page Ltd. Available at: http://site.ebrary.com/lib/librarytitles/docDetail.action?docID=10309992. Accessed: 07.09.2015.

6. Armstrong, M. \& Murlis, H. (2004). Reward management: A handbook of remuneration strategy and practice. 5th edition. London: Kogan Page Limited.

7. Cardy, R.L. \& Dobbins, G.H. (1994). Performance Appraisal: Alternative Perspectives. South Western Publishing Company, Cincinnati, $\mathrm{OH}$.

8. Carrim, Y. (2009). Addressing the financial challenges in municipalities in the context of a review of the local government model. Keynote address of the Deputy Minister of Cooperative Governance and Traditional Affairs to the Institute of Municipal Finance Officers Annual Conference, Johannesburg. Available at: http://www.cogta.gov.za/index.php/news/174-yunus-carrim/264-financial-challenges-in-context-of-review-of-lgmodel-imfo-conference-6-oct-09. Accessed on 12 September 2015.

9. Chaudhary, N. \& Sharma, B. (2012). Impact of Employee Motivation on Performance (Productivity) In Private Organization, International Journal of Business Trends and Technology, 2 (4), pp. 29-35. Available at: https://www.academia.edu. Accessed on 17 October 2015.

10. Clawson, J.G. \& Newburg, D.S. (2005). The motivator's dilemma. In M. Losey (Ed.), Future of human resource management: 64 thought leaders explore the critical HR issues of today and tomorrow, Alexandria, VA: Wiley, pp. 1519. Available at: http://site.ebrary.com/lib/librarytitles/docDetail.action?docID=10114166. Accessed: 12.09.2015.

11. Cronje, G.J., du Toit, G.S. \& Motlatla, M.D.C. (2001). Introduction to Business Management. 5th edition. Cape Town: Oxford University Press Southern Africa.

12. DeCarlo, T.E. \& Leigh, T.W. (1996). Impact of sales person attraction on sales managers' attributions and Feedback, Journal of Marketing, 60 (2), p. 47-66.

13. Dorgan, C.E. (1994). Productivity Link to the Indoor Environment Estimated Relative to ASHRAE 62-1989 Proceedings of Health Buildings '94, Budapest, pp. 461-472.

14. Egberi, E. (2015). Motivation and Employees' Productivity in Local Government System in Nigeria: An Evaluation, Journal for Studies in Management and Planning, 1 (3), pp. 148-163.

15. Ekere, A.U. \& Amah, E. (2014). Staff Benefits and Organizational Performance. A study of Private Hospitals in Rivers State, Nigeria, IOSR Journal of Business and Management, 16 (2), pp. 24-28.

16. Ellickson, M.C. \& Logsdon, K. (2001). Determinants of job satisfaction of municipal government employees, State \& Local Government Review, 33 (3), pp. 173-184.

17. Emerole, O.B. (2015). Effect of Non-Monetary Rewards on Productivity of Employees among Selected Government Parastatals in Abia State, Nigeria, IOSR Journal of Business and Management, 17 (4), pp. 6-11.

18. Gaffoor, S. \& Cloete, F. (2010). Knowledge management in local government: The case of Stellenbosch Municipality, SA Journal of Information Management, 12 (1), pp. 1-7.

19. Green, P.E. (2006). An investigation into the quality of service delivery at the Durban University of Technology Pietermaritzburg Campuses. Master's Degree in Business Management (MBA), University of KwaZulu-Natal, South Africa.

20. Habib, A. (2010). The state of the nation and its public service in contemporary South Africa, Administratio Publica, 18 (3), pp. 2-24.

21. Haenisch, J.P. (2012). Factors Affecting the Productivity of Government Workers, Sage Open, 2 (1), pp. 1-13.

22. Hankin, H. (2004). New workforce: Five sweeping trends that will shape your company's future. Saranac Lake, NY: AMACOM. Available at: http://site.ebrary.com/lib/librarytitles/docDetail.action?docID=10075563. Accessed on 07 September 2015.

23. Jaworski, B.J. \& Kohli, A.K. (1991). Supervisory feedback: alternative types and their impact on sales people's performance and satisfaction, Journal of Marketing Research, 28 (2), pp. 190-201.

24. Katou, A. \& Budhwar, P.S. (2010). Causal relationship between HRM policies and organizational performance: Evidence from the Greek manufacturing sector, European Management Journal, 28 (1), pp. 25-39.

25. Kwak, J. \& Lee, E. (2009). An Empirical Study of "Fringe Benefits" and Performance of the Korean Firms, International Journal of Business and Management, 4, pp. 3-9.

26. Mafini, C. \& Pooe, D. (2013). The relationship between employee satisfaction and organizational performance: Evidence from a South African government department, SA Journal of Industrial Psychology, 39 (1), pp. 1-9.

27. Mazerolle, S.M. \& Goodman, A. (2013). Fulfillment of Work-Life Balance from the Organizational Perspective: A Case Study, Journal of Athletic Training, 48 (5), pp. 668-677. 
28. Minnaar, F. (2006). Integrated performance management: The evolving South African management model, Journal of Public Administration, 41 (21), pp. 177-190.

29. Molefe, G.N., Roodt, G. \& Schurink, W.J. (2011). High performance organization: A quantitative inquiry at a specific metropolitan municipality in the Gauteng Province, African Journal of Business Management, 5 (3), pp. 699-712.

30. Mulder, M. \& Collins, K. (2007). Competence Development in Public and Private Organizations: A Survey of Its Use in Practice in Selected EU Member States. Paper presented at the ECER Conference in Gent, Belgium. September 19. Available at: http://www.mmulder.nl/wp-contentuploads/2011/12/2007-09-19-CompetenceDevelopment-in-P-and-P Organizations.pdf. Accessed 07 September 2015.

31. Nauert, R. (2013). Work-Life Balance Changes Singles - And Everyone Else. Available at: http://psychcentral.com/news/2013/02/22/work-life-balance-challenges-singles-and-everyone-else/51849.html. Accessed: 07 September 2015.

32. Nda, M.M. \& Fard, R.Y. (2013). The Impact of Employee Training and Development on Employee Productivity, Global Journal of Commerce \& Management Perspective, 2 (6), pp. 91-93.

33. Nilsson, J. (2010). What's the problem? Local officials' conceptions of weaknesses in their municipalities' crisis management capabilities, Journal of Contingencies and Crisis Management, 18 (2), pp. 83-95.

34. Okereke, C.I. \& Daniel, A. (2010). Staff Welfare and Productivity in Patani Local Government Council, Delta State, Nigeria, Journal of Economics and International Finance, 2 (12), pp. 313-320.

35. Parker, D., Waller, K. \& Xu, H. (2013). Private and Public services: productivity and performance migration, International Journal of Productivity and Performance Management, 62 (6), pp. 652-664.

36. Pritchard, R.D. (1995) Productivity measurement and improvement: Organizational case studies. Greenwood Publishing Group.

37. Re'em, Y. (2010). Motivating Public Sector Employees: An Application-Oriented Analysis of Possibilities and Practical Tools. Unpublished Master's thesis. Hertie School of Governance, Berlin. Available at: http://www.hertieschool.org. Accessed: 15 September 2015.

38. Rohan, S. \& Madhumita, M. (2012). Impact of Training Practices on Employee Productivity: A Comparative Study, Interscience Management Review (IMR), 2 (2), pp. 87-92.

39. Rolloos, M. (1997). Een gezond binnenmilieu betaalt zichzelf terug Praktijkboek Gezonde Gebouwen. October, A2001-3 18.

40. Schein, E.H. (2006). From brainwashing to organizational therapy: A conceptual and empirical and a general model of change dynamics. A drama in five journey in search of "systemic" health acts, Organization Studies, 27 (2), pp. 287-301.

41. Shaidi, E.W. (2013). Investigation into causes of service delivery protests in Municipalities: A Case Study of Nelson Mandela Bay Municipality. Unpublished Doctoral Philosophiae thesis, Nelson Mandela Metropolitan University (NMMU), Port Elizabeth.

42. Sherwood, M.K. (1994). Difficulties in the measurement of service outputs, Monthly Labor Review, 117 (3), pp. 11-19.

43. Tinofirei, C. (2011). The unique factors affecting employee performance in Non Profit Organizations. Unpublished Magister Technologaie dissertation, University of South Africa, Pretoria.

44. Tokarčíková, E. (2013). Measurement of Highly Qualified Employees Productivity, Annals of Dunarea de Jos University of Galati, 3, pp. 5-10.

45. Verma, H. (2012). Services Marketing, $2^{\text {nd }}$ Edition. Pearson Education, India.

46. Williams, D.W. (2003). Measuring government in the early twentieth century, Public Administration Review, 63, pp. 643-659.

47. Wu, S.Y., Turban, D.B. \& Cheung, Y.H. (2012). Social Skill in Workplace Mentoring Relationships, Journal of Organizational Culture, Communications and Conflict, 16 (2), pp. 51-62. 